\title{
PENGEMBANGAN KOLEKSI DI UPT PERPUSTAKAAN UNIVERSITAS MUHAMMADIYAH MATARAM
}

\author{
Rohana ${ }^{1}$, Widiastuti Furbani 2 \\ Jurusan Ilmu Perpustakaan, Fakultas Ilmu Sosial dan Ilmu Politik \\ Universitas Muhammadiyah Mataram \\ rohana.mip@gmail.com
}

\section{INFO ARTIKEL}

Riwayat Artikel:

Diterima:..........

Disetujui:...-...-...

\section{Kata Kunci:}

Pengembangan, Koleksi

\section{A. PENDAHULUAN}

Sebagaimana yang diamanahkan oleh UndangUndang Republik Indonesia Nomor 43 Tahun 2007 Tentang Perpustakaan (pasal 12) dinyatakan bahwa koleksi perpustakaan diseleksi, diolah, disimpan, dilayankan, dan dikembangkan sesuai dengan kepentingan pemustaka dengan memperhatikan perkembangan teknologi informasi dan komunikasi. Point terakhir di atas menjadi dasar bagi setiap perpustakaan untuk mengembangkan koleksinya dengan terus memperhatikan kebutuhan pengguna sehingga tercapai proses belajar sepanjang hayat (long life education).

Untuk memenuhi kebutuhan informasi masyarakat pengguna, perpustakaan harus mampu mengkaji dan atau mengenali siapa masyarakat penggunanya (pemustaka) dan informasi apa yang diperlukan, mengusahakan dan menjamin tersedianya jasa pada saat diperlukan, serta mendorong pemustaka untuk menggunakan fasilitas yang disediakan oleh perpustakaan. Analisis pemakai dan kebutuhan pemakai perpustakaan bertujuan untuk pengembangan koleksi dalam rangka tersedianya kebutuhan informasi yang benar-benar mutakhir dan relevan dan kontekstual sesuai dengan perkembangan ilmu pengetahuan dan teknologi (Syihabuddin Qalyubi, 2007: 77).

Pengembangan koleksi merupakan rangkaian proses kegiatan yang bertujuan untuk memberi kepastian kepada pengguna perpustakaan bahwa informasi yang disediakan sudah memenuhi 
kebutuhan pengguna secara tepat waktu dan tepat guna. Dengan kata yang lebih sederhana yaitu memastikan kebutuhan informasi pengguna sudah terpenuhi dengan baik sehingga pengguna perpustakaan bisa memanfaatkan sumber-sumber informasi tersebut untuk keperluannya baik dalam pembelajaran, penelitian, pengabdian, dan lain-lain. Oleh karena itu koleksi perpustakaan harus dikembangkan sebaik mungkin dengan memperhatikan kondisi lokal perpustakaan dan masyarakat yang dilayankan.

Dengan konsep pengembangan koleksi yang berorientasi pemustaka, maka kondisi lokal perpustakaan menjadi perhatian penting yang harus diperhatikan. Kondisi lokal (factor internal) yang mempengaruhi proses pengembangan koleksi dapat dijabarkan melalui lima hal, yaitu 1) masyarakat atau institusi, 2) tujuan perpustakaan, 3) kelompok masyarakat atau pengguna yang harus dilayani, 4) koleksi yang telah ada, dan 5) sumber daya yang tersedia meliputi sumber daya manusia, dana, bahan yang tersedia, serta alat bantu untuk untuk identifikasi dan evaluasi yang tersedia (Magrill and Corbin dalam Syhabuddin Qalyubi, 2007: 78).

Dalam upaya memahami kondisi lokal di atas maka upaya pengkajian melalui penelitian harus digalakkkan di setiap perpustakaan terutama perpustakaan perguruan tinggi yang nota benenya mendukung tri dharma perguruan tinggi yaitu pengajaran, penelitian dan pengabdian kepada masyarakat. Karena bagaimanapun, tri dharma tersebut harus dan wajib terpenuh. Bahkan di Universitas Muhammadiyah Mataram memiliki satu tambahan tri dharma yaitu Keislaman dan Kemuhammadiyahan sehingga tidak lagi dikatakan tri dharma melainkan catur dharma perguruan tinggi.

UPT perpustakaan Universitas Muhammadiyah Mataram (UM. Mataram) adalah unit pelaksana tugas yang juga mengantongi beban-beban mulia sebagaimana yang diatur dalam UU RI nomor 43 Tahun 2007 dan mendukung catur dharma perguruan tinggi. Terlebih UM. Mataram dalam tataran lembaga swasta di NTB adalah lembaga yang besar dan banyak peminatnya. Memiliki banyak fakultas yang bernaung dibawah lembaga UM. Mataram seperti fakultas hukum, FKIP, Fisipol, Kesehatan, Teknik, dan pertanian. Sehingga dengan mengacu pada keberagaman disiplin keilmuan tersebut maka koleksi yang harus disediakan juga beragam sesuai dengan kebutuhan fakultas. selain itu jurusan-jurusan juga beragam yang ini menuntut keragaman koleksi yang harus disediakan.

Untuk itulah manajemen pengembangan koleksi yang baik benar-benar dibutuhkan. Visi misi lembaga menjadi perhatian penting bagi perpustakaan dalam pengembangan koleksi karena hal ini mengacu pada tujuan lembaga. Demikian juga dengan catur dharma yang menjadi ciri khas UM. Mataram juga harus dikaji dan dipahami untuk memastikan bahwa koleksi yang dikembangkan oleh UPT perpustakaan UM. Mataram sudah mendukung catur dharma tersebut atau tidak. Diperlukan analisis yang memadai sebelum menyeleksi dan mengadakan koleksi.

Penelitian ini diarahkan nantinya memberi informasi bahwa pengembangan koleksi benarbenar dibutuhkan di lembaga perpustakaan. Atas dasar itulah penelitian ini menjadi begitu penting guna mencapai koleksi yang benar-benar sesuai dengan kebutuhan pengguna. Maka untuk focus penelitian ini diarahkan pada pengembangan koleksi yang meliputi pemilihan (seleksi), pengadaan, evaluasi koleksi, dan penyiangan (deseleksi) koleksi yang ada di UPT Perpustakaan UM. Mataram.

\section{B. RUMUSAN MASALAH}

Dari latar belakang di atas penulis memfokuskan pada dua rumusan masalah yang menjadi titik poin dari pengembangan koleksi yaitu "Bagaimana proses 
pengembangan koleksi yang dilakukan UPT Perpustakaan UM. Mataram”?

"Bagaimana strategi kebijakan pengembangan koleksi yang diterapkan UPT Perpustakaan UM. Mataram"?

\section{TUJUAN PENELITIAN}

Untuk mengetahui bagaimana proses pengembangan koleksi yang dilakukan oleh UPT Perpustakaan UM. Mataram.

\section{LANDASAN TEORI}

1. Pengertian Koleksi

Koleksi menurut UU Republim Indonesia Nomor 43 Tahun 2007 tentang perpustakaan sebagaimana yang tercantum pada pasal 1 ayat 2 adalah semua informasi dalam bentuk karya tulis, karya cetak dan / atau karya rekam dalam berbagai media yang mempunyai nilai pendidikan, yang dihimpun, diolah, dan dilayankan. Kemudian lebih lanjut (pasal 12 ayat 1) koleksi perpustakaan diseleksi, diolah, disimpan, dilayankan, dan dikembangkan sesuai dengan kepentingan pemustaka dengan memperhatikan perkembangan teknologi informasi dan komunikasi. Definisi ini juga sama dengan definisi yang ada di kamus Kepustakawanan Indonesia (Lasa Hs, 2009:176).

Dalam Stnadar Nasional Indonesia Bidang Perpustakaan (2010) dicantumkan pula pengertian dan istilah koleksi perpustakaan (perguruan tinggi) yaitu semua materi perpustakaan yang dikumpulkan, diolah, disimpan, ditemubalik (temu kembali), dan didayagunakan bagi pengguna (pemustaka) dengan tujuan memenuhi kebutuhan mereka. Pengembangan koleksi perguruan tinggi pun harus mengacu pada standar nasional perpustakaan guna mencapai target terhubungnya informasi perpustakaan dengan pengguna sehingga koleksi yang ada di perpustakaan tidak sia-sia. dengan demikian perpustakaan hendaknya tetap memperhatikan koleksi baik judul maupun eksemplarnya, yang mencukupi dan mendukung pelaksanaan pendidikan, penelitian, dan pengabdian kepada masyarakat (UU RI No. 43 Th. 2007 pasal 24 ayat 2).

Dalam menentukan kebijakan koleksi perpustakaan Universitas Muhammadiyah Mataram bisa mengacu pada standar Nasional Indonesia Bidang perpustakaan. Perpustakaan perguruan tinggi menyediakan bahan bacaan wajib dan bahan bacaan pengaya. Perpustakaan juga mengembangkan koleksi menyesuaikan dengan tujuan perguruan tinggi tempat bernaung, yaitu untuk tercapainya catur dharma perguruan tinggi yang dimiliki Universitas Muhammadiyah Mataram. Koleksi yang perlu disediakan perpustakaan perguruan tinggi menurut SNI Bidang perpustakaan ialah:

a. Materi perpustakaan pendukung catur dharma perguruan tinggi. Perpustakaan menyediakan materi tanpa memandang format atau media dalam menunjang kegiatan yang berkaitan dengan pengajaran, penelitian, dan pengabdian serta Keislaman dan kemuhammadiayahan (UMMAT).

b. Materi perpustakaan inti atau bahan ajar untuk keperluan belajar mengajar di UMMAT. Koleksi ini meliputi bahan bacaan untuk mata kuliah yang diampu oleh setiap dosen. Masing-masing judul bahan bacaan tersebut disediakan tiga eksmplar untuk tiap seratus mahasiswa, di mana satu buah buku (1eksemplar) untuk pinjaman dengan jangka pendek dan dua (2) eksemplar lainnya untuk jangka panjang.

c. Terbitan pemerintah. Yaitu terbitan baik terbitan dari daerah maupun pusat.

d. Terbitan perguruan tinggi seperti terbitan lembaga penelitian dan pengabdian, laporan akhir mahasiswa untuk Diploma Tiga, skripsi, tesis, disertasi, karya pengajar, serta karya lainnya yang berkaitan dengan perguruan tinggi tersebut 
e. Terbitan badan internasional

f. Materi perpustakaan referensi seperti catalog induk, abstrak, indeks, Pathfinder, dan lain-lain.

\section{Pengembangan Koleksi Perpustakaan}

Pengembangan koleksi (collection development) diartikan sebagai sebuah kegiatan yang bertujuan untuk menjaga dan memastikan setiap koleksi perpustakaan tetap mutakhir dan sesuai kebutuhan pemustaka. Kegiatan ini meliputi kegiatan menghimpun alat seleksi bahan pustaka, survei bahan pustaka, survei minat pemustaka, meregistrasi bahan pustaka, menyeleksi, mengevaluasi, dan menyiangi koleksi (Lasa Hs, 2009: 245).

Pengertian yang serupa juga ditemukan dalam buku Dasar-Dasar Ilmu Perpustakaan dan Informasi (Syihabuddin Qalyubi, dkk., 2007: 77) bahwa pengembangan koleksi yaitu serangkaian proses atau kegiatan yang bertujuan mempertemukan atau menjembatani pemakai dengan rekaman informasi dalam lingkungan perpustakaan atau unit informasi. Kegiatan pengembangan koleksi ini mencakup, antara lain penyusunan kebijakan pengembangan koleksi, pemilihan, pengadaan, penyiangan, serta evaluasi pendayagunaan koleksi. Kebijakan koleksi bertujuan untuk memastikan bahwa kebutuhan informasi pemustaka benar-benar terpenuhi secara tepat waktu dan tepat guna melalui pemanfaatan sumber-sumber yang disediakan oleh perpustakaan. Oleh karena itu sebelum melakukan proses pemilihan koleksi sangat penting mensurvei atau menganalisis kebutuhan pengguna perpustakaan selain menganalisis kondisi perpustakaan secara internal seperti SDM, SDA yang ada, dana, dan lain sebagainya.

Dalam pengertian di atas terdapat beberapa poin penting yang mesti ada di dalam pengembangan koleksi yaitu pengetahuan mengenai kondisi pemustaka, tujuan perpustakaan atau kondisi lokal perpustakaan, koleksi yang telah ada, dan koleksi yang terseleksi dengan tepat dan benar, serta kebijakan yang ada yang menjadi pedoman pengembangan koleksi.

Seleksi yaitu proses, tindakan, atau cara memilih. Lasa (2009: 310) menyebutkan bahwa seleksi koleksi yaitu penilaian desiderata dan memberikan pertimbangan dalam pengadaan bahan pustaka suatu perpustakaan berdasarkan kebutuhan pemustaka dan kebijakan pengembangan koleksi. Secara sederhana seleksi koleksi yaitu proses memilih bahan pustaka dengan mengacu pada kebijakan pengembangan koleksi dan mengacu pada kepentingan pemustaka.

Ada beberapa tahapan sebelum memilih bahan pustaka yang akan diadakan antara lain:

a. Analisis pemakai, dalam hal ini perpustakaan perguruan tinggi memperhatikan kebutuhan pemakai melalui survei, baik secara langsung atau tidak langsung.

b. Menganalisis bahan koleksi yang telah ada

c. Membuat skala prioritas, mana bahan pustaka yang harus segera disediakan dan mana yang akan ditunda dulu pengadaannya

d. Menganalisis dana yang tersedia

e. Memperhatikan SDM yang tersedia yang bertanggungjawab terhadap penyeleksian

f. Membentuk tim seleksi

Dalam proses seleksi, sebelum bahan pustaka ditetapkan untuk diadakan maka perlu memperhatikan sumber-sumber seleksi yang mencakup alat bantu seleksi dan alat identifikasi dan verifikasi. Alat bantu seleksi bisa berupa majalah tinjauan buku (reviewing journals), dan daftar judul untuk jenis perpustakaan tertentu (core list).

Sementara untuk alat identifikasi dan verifikasi dapat berupa catalog penerbit, bibliografi, indeks dan lain-lain.

Setelah proses seleksi selesai maka bahan pustaka segera diadakan. Pengadaan bahan pustaka merupakan proses mengadakan koleksi 
melalui beberapa cara seperti pembelian, tukar menukar, hadiah, hibah, dan penerbitan sendiri.

Penyiangan sebagai bagian kegiatan pengembangan koleksi juga sangat penting untuk menjaga kekinian koleksi dan efisiensi. Penyiangan merupakan upaya pengeluaran koleksi tertentu dari perpustakaan karena tidak relevan, tidak diminati lagi, sudah kadaluwarsa, terlalu banyak eksemplarnya, telah ada edisi yang baru, maupun karena koleksi itu termasuk buku atau karya yang dilarang. Koleksi ini dapat ditukarkan dengan koleksi perpustakaan lain, dihadiahkan, maupun dihancurkan untuk pembuatan kertas lagi.

\section{E. METODE PENELITIAN}

Penelitian ini merupakan penelitian lapangan (field research) yang disertai atau didukung dengan data kepustakaan (library research). Untuk penelitian lapangan peneliti menggunakan metode observasi dan wawancara (interview). Sedangkan untuk mendapatkan data-data kepustakaan yang menyangkut pengembangan koleksi di UPT perpustakaan UMMAT yang merupakan tema pokok penelitian ini penulis menggunakan analisis isi (content analysis) (Babbie, 1980: 267).

Sumber data penulis dapatkan dari wawancara mendalam sebagai sumber primer yang akan ditujukan kepada kepala perpustakaan sebagai orang yang bertanggungjawab terhadap kinerja bawahan, pustakawan di bidang pengembangan atau pengadaan, dan pustakawan lain yang menangani masalah koleksi untuk memperoleh data koleksi perpustakaan. Sementara data sekunder bisa diperoleh dari berbagai sumber data dan kepustakaan, buku, ensiklopedi, majalah, jurnal penelitian dan sebagainya.

Struktur pengumpulan dan klasifikasi data dilakukan dengan teknik observasi langsung dan wawancara mendalam. Cara kerja dari model tersebut, yaitu observasi partisipasi dan wawancara mendalam sebagai perangkat utama untuk mengumpulkan data kualitatif yang bersifat subjektif. Karena penelitian kualitatif erat kaitannya dengan faktor kontekstual, keunikan, dan setiap konteks hanya dipahami dari konteksnya sendiri, maka sampling penelitian dimaksudkan lebih pada upaya menjaring sebanyak mungkin informasi dan kedalaman informasi dari berbagai sumber, tidak bergantung pada banyaknya informan yang diwawancarai. Teknik Pengolahan Data penulis lakukan dengan metode dekriptif sedangkan analisisa data yang digunakan adalah teknik analisis isi (content analysis) yaitu menganalisa masalah pokok yang diteliti menurut isinya secara kualitatif (Krippendorff, 1991: 15). Menurut Earl Babbie (1980: 267) bahwa content analysis adalah suatu upaya yang sdilakukan dalam rangka menelaah maksud dari isi informasi yang termuat dalam dokumen, seperti dokumen dalam bventuk syair, lukisan, pidato tertulis, naskah peraturan atau perundangundangan.

\section{F. PEMBAHASAN}

1. Proses Pengembangan Koleksi UPT Perpustakaan UM. Mataram

Kegiatan pengembangan koleksi perpustakaan berfungsi sebagai penghubung atau mediator antara pemakai dengan rekaman informasi yang disediakan perpustakaan. Dengan fungsi tersebut diharapkan pemakai dapat memanfaatkan perpustakaan sebaik mungkin guna memenuhi kebutuhannya dan perpustakaan menjalankan fungsinya sebagaimana mestinya. Pengembangan ini mencakup pemilihan (seleksi), analisis pemakai, pembentukan tim seleksi, kriteria seleksi, sumber-sumber seleksi, pengadaan, dan penyiangan koleksi.

\section{a. Pemilihan (seleksi)}

Secara umum seleksi berarti tindakan, cara, atau proses memilih. Dalam hubungannya dengan pengembangan koleksi perpustakaan, seleksi merupakan kegiatan untuk 
mengidentifikasi rekaman informasi yang akan ditambahkan pada koleksi yang sudah ada di perpustakaan. Proses yang dilakukan pada tahap ini adalah keputusan untuk mencantumkan atau tidak rekaman informasi yang direncanakan untuk diadakan perpustakaan. Dengan demikian, sebagaimana yang diungkapakan oleh Bahauddin selaku kepala UPT Perpustakaan UM. Mataram bahwa proses seleksi merupakan kegiatan yang dilaksanakan sebelum kegiatan pengadaan bahan pustaka (wawancara tanggal 3 Juli 2017 pukul 11.30 Wita).

Dalam penyeleksian bahan pustaka, UPT UMMAT mencoba menggabungkan antara kualitas bahan dan selera masyarakat. Artinya dalam hal isi penting dan kebutuhan selera masyarakata juga penting.

"Jadi, dalam penyeleksian bahan pustaka kita melihat dulu kebutuhan mahasiswa, namun tidak semua kebutuhan mahasiswa harus kita tampung karena terkadang mahasiswa hanya merekomendasikan buku-buku yang sifatnya menunjang saja seperti cerpen, komik, dan laian-laian. Sementara untuk keperluan kuliah diabaikan".

\section{b. Analisi Pemakai}

Analisis pemakai merupakan proses menggali kebutuhan pemustaka yang memanfaatkan perpustakaan melalui cara-cara tertentu seperti survei, penelitian, atau pendataan pemanfaatan koleksi yang ada di perpustakaan. Analisis pemakai sangat penting dilakukan untuk memastikan kebutuhan pemustaka sudah benar-benar terpenuhi atau tidak adan agar koleksi yang disediakan tidak sia-sia. tujuan lainnya adalah untuk menetapkan jumlah eksemplar buku yang akan disediakan dengan melihat jumlah pemakai yang memanfaatkan suatu koleksi perpustakaan.

UPT perpustakaan UM. Mataram sudah melakukan analisis pemakai, meskipun belum maksimal. Cara yang digunakan melalui pendataan terhadap koleksi yang sering digunakan dan jarang digunakan. Dengan cara ini maka perpustakaan dapat melihat mana koleksi yang perlu ditambah eksemplarnya dan mana koleksi yang tidak perlu lagi diadakan. Sebagaimana yang dikatakan oleh Bahuddin bahwa:

"kami mendata koleksi yang sering dipakai untuk melihat kebutuhan pemustaka. Kalau sering diapakai berarti koleksi tersebut memang sangat dibutuhkan, sehingga dengan begitu kami akan menambah eksemplarnya. Kalau yang jarang dipinjam atau dipakai, ya kami tidak adakan lagi”.

Hal ini dikuatkan juga oleh Mariana Rahmawati selaku pustakawan bidang pelayanan teknis bahwa:

"untuk mendukung kebutuhan pemakai kami melakukan analisis dengan melihat peminjam yang ada di perpustakaan. Selain itu dengan cara memberikan mereka blanko usulan buku atau koleksi yang mereka butuhkan"

Meskipun analisis pemakai yang sudah dilakukan oleh UPT perpustakaan UM. Mataram belum maksimal terutama karena hanya melakukan satu cara, namun hal ini menunjukkan bahwa proses pengembangan koleksi sudah berjalan. Idealnya adalah analisis pemakai dilakukan dengan beberapa cara agar kebutuhan benar-benar diketahui.

Kelemahan dari cara yang digunakan UPT perpustakaan UM. Mataram adalah dengan cara mendata koleksi yang sering digunakan hanya mampu melihat kebutuhan koleksi yang sudah dimanfaatkan, kemudian ini menjadi acuan untuk menambah eksmemplar. Sementara kebutuhan koleksi pada saat ini untuk kemudian diadakan tidak terakomodasi. Sehingga cara sudah dilakukan UPT perpustakaan UM. Mataram hanya untuk menambah eksemplar, bukan untuk menambah judul atau subjek 
koleksi yang perlu diadakan. Perlu ada peninjauan kembali bagaimana metode yang cocok untuk melakukan proses analisis pemakai sehingga kebutuhan pemustaka dipastikan benar-benar tersedia nantinya.

\section{c. Tim Seleksi}

Tim seleksi merupakan kelompok oaring atau personalian yang terlibat dalam proses seleksi. Di perpustakaan, personalia ini biasanya berdasarkan tipe perpustakaan itu sendiri. Secara umum personalia atau kelompok yang dipandang memiliki kapabilitas untuk menyeleksi bahan pustaka antara lain, 1) pustakawan, 2) spesialis subjek, 3) took buku, 4) komisi perpustakaan. Meskipun demikian, kenyataan di lapangan menunjukkan bahwa otoritas yang melakukan seleksi ditentukan oleh tipe atau menurut jenis perpustakaan.

Untuk perpustakaan perguruan tinggi otoriras yang melaksanakan seleksi adalah pimpinan universitas, dekan, ketua jurusan/program studi, dan dosen. Pembentukan komisi penasihat/pengawas perpustakaan secara khusus juga dapat memilih atau menyarankan agar melanggan terbitan berkala tertentu sebagai salah satu tugasnya. Komisi ini biasanya terdiri dari pustakawan, dosen, dekan, dan elemen-elemen lain yang dipandang mampu. Mahasiswa dimungkinkan member usulan, tetapi dengan mempertimbangkan keselarasan kebutuhan perpkuliahan (Syihabuddin Qalyubi dkk, 2007: 83).

UPT perpustakaan UM. Mataram secara khusus belum memiliki tim seleksi yang ditunjuk untuk memegang otoritas dalam seleksi koleksi. Sehingga dalam hal ini yang berperan sebagai selektor adalah pustakawan dan pimpinan universitas (karena menyesuaikan dengan anggaran). Sebagaimana yang diungkapakan oleh Bahauddin bahwa: “di sini belum ada tim seleksi yang dibentuk secara khusus, yang menyeleksi bahan pustaka adalah pustakawan itu sendiri. Semua pustakawan termasuk kepala dan staff. Dosen belum dilibatkan. Adapun mahasiswa cuma dimintakan usulan untuk koleksi mana yang mereka butuhkan. Ya caranya dengan memberikan mereka blanko usulan, lalu mereka isi.”

Sebelum perpustakaan tersentralisasi, program studi juga dilibatkan dalam proses seleksi, namun hanya sebagai pemberi usulan sama halnya dengan mahasiswa. Jadi, setiap jurusan atau program studi diminta untuk memberi daftar ususlan buku yang mereka butuhkan, namun yang menyeleksi tetap pustakawan dan nantinya ditetapkan oleh pimpinan universitas.

Adapun criteria tim seleksi yang diidealkan UPT perpustakaan UM. Mataram adalah orang yang memiliki pengetahuan banyak mengenai koleksi. Hal ini sebagaimana yang disebut oleh Bahauddin dan Wahyuni bahwa dosen harusnya terlibat di dalam proses seleksi.

“ Dalam proses seleksi doses memang harusnya terlibat. Terutama untuk memenuhi kebutuhan mahasiswa dalam proses perkuliahan. Selain itu orang yang menyeleksi juga mengetahui kebutuhan user. Pustakawan dalam hal ini tepat sebagai tim seleksi”

Tim seleksi memang diperlukan. Hal ini sangat disadari oleh UPT perpustakaan UM. Mataram meskipun kenyataanya tim seleksi ini belum terbentuk. Ini dikarenakan belum adanya manajemen pengembangan koleksi yang terarah di UPT perpustakaan UM. Mataram. Kesadaran akan pentingnya tim seleksi menunjukkan ada kemungkina untuk memperbaiki manajemen pengembangan koleksi nantinya agar pengembangan koleksi bisa menjadi jembatan 
atau penghubung antara koleksi yang disediakan dengan pemustaka yang memanfaatkan koleksi.

\section{d. Kriteria seleksi}

Uraian criteria yang digunakan sebagai bahan evaluasi bahan pustaka yang akan dipilih untuk diadakan dapat dideskripsikan secara lebih rinci atau dengan cara yang lebih sederhana. Persoalan semacam ini bisa diterapkan tergantung pada kesepakatan perpustakaan. Jadi, tidak ada aturan yang baku untuk semua perpustakaan bahwa criteria seleksi harus seperti ini atau seperti apa. Perpustakaan bisa menerapkan criteria yang digunakan bergantung dari visi dan misi perpustakaan itu sendiri.

UPT perpustakaan UM. Mataram sebagaimana yang dikatakan Bahauddin dan Mariana Rahmawati bahwa ada criteria-kriteria yang dipilih dalam menyeleksi bahan pustaka sebelum diadakan. Criteria tersebut antara lain:

1) Kegunaan koleksi

Koleksi yang diseleksi adalah koleksi yang paling sering digunakan dan sedikit eksemplarnya. Koleksi yang paling sering digunakan dipilih untuk ditambah eksemplarnya dan yang sedikit eksemplarnya dipilih untuk ditambah lagi eksemplarnya. Hal ini untuk memenuhi kebutuhan pemustaka agar koleksi yang dibutuhkan dapat dibaca atau dipinjam tanpa harus menunggu pengembalian dari peminjam sebelumnya.

2) Tingkatan koleksi

Tingkatan koleksi yang dipilih UPT perpustakaan UM. Mataram adalah karya ringan dan popular, karya popular yang serius, karya elementer, dan karya standar. Adapaun karya yang tingkat ilmiahnya lebih tinggi seperti tesis dan disertasi belum dipilih karena di UM. Mataram belum memiliki program pasca sarjana. Sehingga dianggap karya tersebut belum dibutuhkan.

3) Otoritas dan kridibitas pengarang

Koleksi dipilig yang sesuai dengan latar pendidikan penulisnya. Jika ada dua judul buku yang mirip atau subjek buku tersebut hamper sama, maka yang dipilih adalah yang memiliki kualifikasi pendidikan yang sesuai dengan buku yang ditulis.

4) Harga

Harga menyesuaikan dengan anggaran pertahun dan atas persetujuan dari tim pengadaan universitas. Sebelum tersentralisasi, anggaran untuk perpustakaan diambil dari sumbangan mahasiswa yaitu sebanyak 75 ribu per/mahasiswa. Hal ini berarti anggaran untuk koleksi perpustakaan bergantung dari banyaknya mahasiswa yang diwisuda, karena sumbangan 75 ribu tersebut adalah dari mahasiswa yang akan diwisuda. Namun, setelah tersentralisasi, anggaran koleksi pertahun diambil dari RPBU (rencana pendapatan belanja universitas) sejumlah 100 juta. Anggaran ini untuk pembelian buku pertahuan yang ditujukan untuk semua jurusan atau prodi yang ada di UM. Mataram.

Oleh karena itu harga yang dipilih UPT Perpustakaan UM. Mataram adalah harga rata-rata yang bisa memenuhi kebutuhan prodi di lingkungan UM. Mataram.

5) Kemutakhiran

UPT perpustakaan UM. Mataram memilih koleksi yang terbaru dan memiliki edisi revisi.

6) Penyajian fisik buku

Dipilih buku yang tidak menggunakan kertas buram, bersih, rapi, dan memiliki penyajian menarik. 
Adapun criteria di atas agar dapat dilihat secara jelas dapat dituangkan dalam bentuk tabel sebagai berikut:

Tabel 1. Penyajian Fisik Buku

\begin{tabular}{|c|c|c|}
\hline No. & KRITERIA & ITEM CRITERIA \\
\hline 1 & KEGUNAAN KOLEKSI & $\begin{array}{l}\text { 1. KOLEKSI YANG PALING } \\
\text { SERING DIGUNAKAN } \\
\text { 2. KOLEKSI YANG SEDIKIT } \\
\text { EKSEMPLAR }\end{array}$ \\
\hline 2 & TINGKATAN KOLEKSI & $\begin{array}{l}\text { 1. KARYA RINGAN DAN } \\
\text { POPULAR, KARYA } \\
\text { POPULAR YANG SERIUS, } \\
\text { KARYA ELEMENTER, } \\
\text { KARYA STANDAR } \\
\end{array}$ \\
\hline 3 & $\begin{array}{l}\text { OTORITAS DAN } \\
\text { KREDIBILITAS } \\
\text { PENGARANG }\end{array}$ & $\begin{array}{l}\text { 1. PENGARANG DENGAN } \\
\text { LATAR PENDIDIKAN } \\
\text { YANG SESUAI DENGAN } \\
\text { BUKU YANG DITULIS } \\
\end{array}$ \\
\hline 4 & HARGA & $\begin{array}{ll}\text { 1. } & \text { HARGA MENGIKUTI } \\
& \text { ANGGARAN } \\
& \text { UNIVERSITAS } \\
\text { 2. } & \text { HARGA RATA-RATA } \\
& \text { YANG MEMENUHI } \\
& \text { KEBUTUHAN KOLEKSI } \\
& \text { SEMUA JURUSAN ATAU } \\
\text { PRODI UM. MATARAM } \\
\end{array}$ \\
\hline 5 & KEMUTAKHIRAN & $\begin{array}{ll}\text { 1. } & \text { KARYA TERBARU } \\
\text { 2. } & \text { KARYA YANG MEMILIKI } \\
\text { EDISI REVISI }\end{array}$ \\
\hline 6 & $\begin{array}{l}\text { PENYAJIAN DAN FISIK } \\
\text { BUKU }\end{array}$ & $\begin{array}{ll}\text { 1. } & \text { KERTAS STANDAR, } \\
\text { TIDAK MENGGUNAKAN } \\
\text { KERTAS BURAM } \\
\text { 2. } \\
\text { RAPI, BERSIH, DAN } \\
\text { MENARIK }\end{array}$ \\
\hline
\end{tabular}

7) Sumber-sumber seleksi

Sumber seleksi yang digunakan sebagai alat bantu seleksi dan identifikasi adalah catalog penerbit. Sumber ini biasa digunakan oleh perpustakaan guna mendapatkan informasi mengenai buku-buku yang ada di penerbit. Selain catalog penerbit sumber lain yang digunakan perpustakaan adalah daftar buku yang disediakan oleh toko buku. Toko buku biasanya akan mendata semua buku yang disediakan untuk menjadi informasi bagi pembeli terutama dalam jumlah besar. Toko buku tidak hanya menyediakan buku dari satu penerbit, bisa juga dari berbagai penerbit tergantung dari kelengkapan subjek yang dibutuhkan pengguna.
UPT perpustakaan UM. Mataram selain dari catalog dan daftar buku dari toko buku juga menggunakan sumber lain yaitu catalog yang disediakan di internet. Sekarang ini pembelian buku memang tidak hanya melalui penerbit atau toko buku yang memiliki bangunan saja, melainkan juga bisa secara online dengan metode pembelian sesuai dengan dunia maya. Kemudahan yang diperolehpun begitu terbuka bagi perpustakaan.

8) Pengadaan

Secara sederhana, pengadaan merupakan proses mengadakan koleksi setelah melalui kegiatan seleksi. Pengadaan bahan pustaka secara umum dapat dilakukan melalui cara pembelian, tukar menukar, hadiah, atau dengan cara menerbitkan sendiri. Bahan pustaka yang akan diadakan mencakup karya cetak atau karya grafis seperti buku, majalah, surat kabar, skripsi, laporan akhir, laporan penelitian, tesis, dan disertasi. Adapun karya non cetak mencakup piringan hitam, rekaman audio, kaset, dan video.

Selain dengan cara pembelian, UPT perpustakaan UM. Mataram juga melakukan pangadaan koleksi dengan cara hadiah. Proses hadiah dilakukan dengan tanpa mengirimkan terlebih dahulu daftar koleksi yang dibutuhkan. Melainkan dengan menerima hadiah yang dikirimkan oleh pemberi hadiah. Setelah buku diterima, pustakawan kemudian menerima hadiah tersebut dan mengirimkan surat tanda terima serta ucapan terima kasih.

Koleksi buku yang diterima dari hadiah selanjutnya diolah sebagaimana biasanya mulai dari inventarisasi, pemberian stempel, klasifikasi, katalogisasi, pemberian barcode, dan pengerakan (selving). 
Penerimaan hadiah koleksi biasanya didapatkan dari perpustakaan nasional dan perpustakaan daerah. Apabila ada koleksi yang tidak sesuai dengan kebutuhan, maka koleksi tersebut bisa dihadiahkan lagi ke perpustakaan lain yang membutuhkan koleksi tersebut.

9) Sumbangan

Salah satu cara pengadaan koleksi di UPT perpustakaan UM. Mataram adalah melalui sumbangan, baik dari mahasiswa atau dari dosen. Biasanya mahasiswa yang menyumbangkan koleksi adalah mahaiswa yang sudah diwisuda. Dosen menyumbang buku hasil tulisannya sendiri atau dari tulisan orang lain karena merasa perlu memberikan andil dalam pengembangan perpustakaan.

Sumbangan koleksi ini tidak dipaksa melainkan karena keinginan sendiri dari penyumbang. Prosesnya sama dengan hadiah. Setelah buku diterima, dibuatkan surat tanda terima dan ucapan terima kasih.

10)Penyiangan (deseleksi)

Perawatan koleksi (Collection maintenance) merupakan bagian pengelolaan (collection management) yang meliputi pelbagai kegiatan yang bertujuan menjaga kemutakhiran dan daya guna koleksi perpustakaan. Salah satu bagian perawatan koleksi adalah desleksi atau penyiangan.

Pada prinsipnya penyiangan atau yang disebut deseleksi merupakan kegiatan mengeluarkan koleksi dari rak akibat koleksi tersebut sudah di up to date, rusak, atau tidak dimanfaatkan oleh pemakai. Penyiangan yang dilakukan di perpustakaan memiliki tujuan antara lain:

a) Memperoleh tambahan tempat (shelf space) untuk koleksi yang baru

b) Membuat koleksi lebih dapat dimanfaatkan sebagai sumber informasi yang akurat, relevan, up to date, serta menarik

c) Memberikan kemudahan pada pemakai dalam menggunakan koleksi

d) Memungkinkan staf perpustakaan mengelola koleksi secara lebih efektif dan efisien.

Di UPT perpustakaan UM. Mataram penyiangan pernah dilakukan sekali. Tidak ada aturan yang jelas dan baku mengenai penyiangan ini. Apabila koleksi sudah dianggap perlu dikeluarkan, maka proses penyiangan bisa dilakukan.

Menurut Bahauddin dan Sri Wahyuni, penyiangan dilakukan dengan syarat:

a) Koleksi sudah rusak

b) Koleksi sudah kadaluarsa

c) Koleksi tidak dimanfaatkan lagi oleh pemakai perpustakaan

Adapun prosesnya adalah:

a) Pendataan koleksi

Koleksi yang ada di rak didata dahulu apakah ada yang kadaluarsa, rusak baik rusak karena sobek ataupun karena kadaluarsa. Setelah itu baru dipisahkan dari rak semula

b) Setelah terdata, maka koleksi tersebut dikeluarkan kemudian di input

c) Setelah keluar dari rak koleksi dipindahkan ke gudang atau dihadiahkan ke perpustakaan lain yang membutuhkan. 


\section{G. KESIMPULAN}

Kegiatan pengembangan koleksi di UPT Perpustakaan Universitas Muhammadiyah Mataram (UMMAT) memiliki tujuan untuk memastikan bahwa informasi yang diolah, dilayankan, serta disebarluaskan sampai kepada pengguna (pemustaka). Oleh karena itu UPT perpustakaan UMMAT melakukan kegiatan pengembangan sesuai dengan tahapan sebagaimana yang biasa dilakukan sebelumnya. Pengembangan tersebut meliputi pemilihan (seleksi), analisis pemakai, pembentukan tim seleksi, kriteria seleksi, sumber-sumber seleksi, pengadaan, dan penyiangan koleksi. Bebarapa hal yang belum maksimal seperti tim seleksi bersifat penunjukan atau tidak tertulis (ditunjuk) menjadi bahan evaluasi bagi pengembangan ke depan. Selain itu proses yang belum maksimal terkait dengan tahapan-tahapan tersebut akan diupayakan ke depan semakin baik mengingat SDM perpustakaan semakin memadai dengan bertambahnya pustakawan S1 dan S2 bidang ilmu perpustakaan.

\section{DAFTAR PUSTAKA}

Babbie, Earl. 1980. The Practice of Social Research. California: Belfast.

Bakker, Anton dan Achmad Charis Zubair. 1997. Metodologi Penelitian Filsafat. Yogyakarta: Kanisius.

Basuki, Sulistyo. 1993. Pengantar Ilmu Perpustakaan. Jakarta: Penerbit PT Gramedia Pustaka Utama.

Lasa Hs. 2009. Kamus Kepustakawanan Indonesia. Yogyakarta: Pustaka book Publisher.

Lupone, George (ed.). 2009. New York: Routledge Taylor $\&$ Prancis Group.

Moeleong, Lexy. 1995. Penelitian Kualitatif, Fenomena Sosial dalam Kehidupan Masyarakat. Bandung: Rosdakarya.

Nazir, Moh. 1981. Metode penelitian. Jakarta: Ghalia Indonesia.

Nakosteen, Mehdi. 1996. Kontribusi Islam atas Dunia Intelektual Barat: Deskripsi Analisis Abad keemasan. Surabaya: Risalah Gusti.

Qalyubi, Syihabuddin, dkk. 2007. Dasar-Dasar Ilmu Perpustakaan dan Informasi. Yogyakarta: Jurusan Ilmu Perpustakaan dan Informasi (IPI) Fakultas Adab UIN Sunan Kalijaga.

Suprayogo, Imam dan Tobroni. 2003. Metodologi Penelitian Sosial Agama. Bandung: Rosdakarya.

Sutarno NS. 2005. Tanggung Jawab perpustakaan. Jakarta: panta Rei.

Tim Panitia Teknis Bidang Perpustakaan Standar Nasional Indonesia. 2010. Standar nasional Indonesia (SNI) Bidang perpustakaan. Jakarta: Perpustakaan nasional RI.

Undang-Undang republic Indonesia Nomor 43 Tahun 2007 Tentang Perpustakaan. 